\title{
Factors Affecting Small Scale Farmers Coping Strategies To Climate Change In Kakamega County In Kenya
}

\author{
Mulinyac. ${ }^{1}$ \\ 1.MasindeMuliro University of Science and Technology
}

\begin{abstract}
This study examines the adaptation strategies to climate change of small scale farmers in Kakamega County in Kenya.Kakamega County is a rich agricultural area where various food and cash crops are grown. However, changes in climate coupled with declining soil fertility over the area have an impact on crop production, and hence affect food security especially among small scale farmers. The study sought to examine farmer's perceptions to climate change and factors that influenced small scale farmers in adapting to climate change. The study adopted a descriptive survey design. Data from both primary and secondary sources were used. Primary data included Focal Group Discussions (FGDs), questionnaires and interview schedules administered to farmers to gain information onfarmer's perceptions to climate change, adaptation strategies to climate change if any and factors likely to influence their adaptation strategies. Despite these changes in climate crop farmers had put in practice some adaptation strategies to cope with the changing trends, though they were faced with many challenges/ constraints in trying to implement these strategies and this was related to certain factors.Results indicated that a majority of the farmers engaged in adaptive strategies to climate change. Out of 9 adaptation strategies that the farmers were aware of, planting of drought tolerant crops was ranked firstamong farm adaptive measures, while rain water harvesting was ranked as least utilized. Out of seven factors surveyed, age, education, family size, farm size, family income, genderand farming experiences were significantly related toadaptation strategies. Despite different support and technological interventions being available, lack of finances, lack of information, shortage of labour expertise were noted by the respondent as major constraints to coping with climate change effects. These results provide policy makers and development service providerswith important insight, which can be used to better target interventions which buildpromote or facilitate the adoption of coping mechanisms with potential to build resiliencyto changing climate and resulting environmental impacts.
\end{abstract}

Key Words: Climatic Change, Adaptation Strategies, constraints, Small scale farmers.

\section{INTRODUCTION}

Agriculture is extremely vulnerable to climate change, the agricultural sector in developing countries is particularly vulnerable to adversities of weather, not only because farmers are dependent on rain but because farming is subsistence oriented and is practiced not only with relatively basic knowledge but also using technologies on small pieces of land. The small holder farmers already practice farming under pressure from food insecurity, increased poverty and water scarcity (Oxfam 2010, CEEPA 2006, Regassaet al., 2010). The issue of climate change as witnessed in the $21^{\text {st }}$ century is a major threat facing humanity. The fourth assessment report of Intergovernmental Panel on Climate Change (IPCC) of 2007 indicated that warming of climate is unequivocal and observations show an increase in global average air and ocean temperature, widespread melting of snow and rising global mean sea level. At continental and regional levels, numerous long term changes in climate have been observed and include widespread changes in precipitation amounts and distribution, ocean salinity, wind patterns and aspects of extreme weather resulting to droughts, heat waves, and intensity of tropical cyclones. These changes threaten community livelihoods, food security, economic sectors, ecosystems and social groups (Watson et al., 1998; O Brien and Leichiko, 2000). The socio-economic sectors that are adversely affected include water resources, agriculture, forestry, fisheries and human settlements, ecological and human health.Additional pressures emanate from higher air and soil temperatures which eventually reduce yields of desirable crops while encouraging weed and pest proliferation. Further changes in precipitation patterns increase the likelihood of short-run crop failures and long-run production declines. Although there will be gains in some crops in some regions of the world, the overall impacts of climate change, the focus of this study are expected to be negative, threatening global food security.(IPCC,2007).The Inter Governmental Panel on Climate Change (IPPC, 2007) highlighted that Africa will be one of the continents that will be hard hit by the impact of climate change due to an increased temperature and water scarcity and yet Africa represents only 3.6 percent of emissions. The IPCC Report pointed out that there is "very high confidence" that agricultural production and food security in many African countries could be severely affected by climate change and variability. The 
Report projected that yields of crops in some countries could be reduced to as much as 50 percent by 2020, with small-scale farming being the most affected.Agriculture is at the forefront of shaping the concept of sustainable development for many developing countries, particularly Kenya. The renewed attention for the role of agriculture in development processes will have to take account of the vulnerabilities and risks posed by climate change.In Kenya the general observation is that impacts of climate change exist and may have affected some of the keysectors of the economy which are highly depended upon by the local communities. Agricultural production, environment, energy, forest, tourism, infrastructure and public health are bearing much of the impact. At the moment the country is facing severe drought that has resulted in extreme hunger among some parts of the population and the death of significant numbers of livestock, power rationing and increased conflicts over dwindling water resources.(Kuria,2009).Changes in climate and weather patterns particularly rainfall regimes are predicted to have severe negative impacts on crop production, food security and natural resources in East Africa. Without appropriate responses climate change, is likely to constrain economic development and poverty reduction efforts and exacerbate already pressing difficulties. Countries with economies rooted in climate sensitive sectors like agriculture, fisheries and forestry are expected to be hardest hit. (Woodhill and Terswichha, 2007). This is likely to affect livelihoods of people who are dependent on rain fed agriculture.Crop production is highly sensitive to climate variability and weather extremes, such as droughts, floods and severe storms. The forces that shape our climate are critical to farm productivity. Human activities have already changed atmospheric conditions such as temperature, rainfall, levels of carbon dioxide and ground level ozone (Thornton et. al., 2006). While food production may benefit from a warmer climate in temperate regions (IPCC 2007) the increased potential for droughts, floods and heat waves will pose challenges for farmers. Additionally, the enduring changes in climate, water supply and soil moisture could make it less feasible to continue crop production in certain regions. Recent studies in Kenya indicate that increased frequency of heat stress, droughts and floods affect crop yields and livestock beyond the impacts of mean climate change, creating the possibility for surprises, with impacts that are larger and occurring earlier, than predicted using mean variables alone.( Kuria, 2009). This is especially the case for subsistence sectors of farming at low latitudes.

On the basis of the aforesaid, the main objective of this study was to investigate climatic changes and their impact on small scale farmers, response adaptation strategies factors affecting their coping strategies and constraints to adapting to climate change in Kakamega County. Specifically, the study sought to analyse patterns and trends and farmers perceptions of climate change in Kakamega County between 1968 and 2014 and assess coping strategies to such climate changes, constraints to adapting and how these impact on small scale farmers and factors influencing the coping strategies in Kakamega County in Western Kenya.

\section{METHODOLOGY}

The study adopted a descriptive survey design because of the large amount of data from the population regarding resilience to climate change impacts by small scale farmers in Kakamega county of Kenya.

\subsection{Study Area}

Kakamega County is located in the former Western Province of Kenya. Its capital is Kakamega and its largest town is Mumias. It has a population of 1,660,651 and an area of 3,224.8 $\mathrm{km}^{2}$. It is located on coordinates: $0.283333^{\circ} \mathrm{N} 34.75^{\circ} \mathrm{E}$ and covers an area of $3224.9 \mathrm{KM}^{2} \mathrm{It}$ is located at an altitude of $1520-1680$ metres above sea level and has 12 sub counties namely Lugari, KakamegaSouth,NavakholoMumias, Likuyani, Malava,Matete,Kakamega East, Butere, KakamegaCentral,Matumgu and Khwisero, (Kakamega CDP, 2013as shown in Fig. 1 below.

Figure 1.0 Map showing Kakamega County administrative units

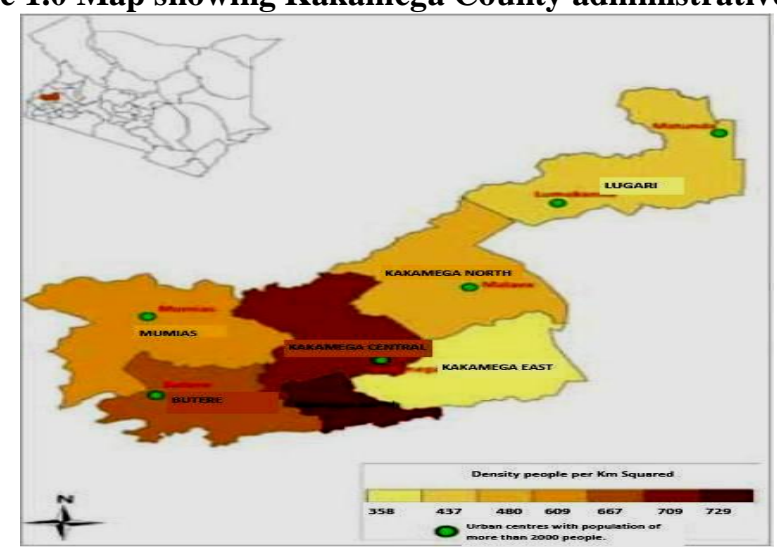


The soils are deficient in nitrogen and phosphorous though efforts are being made to address thedeclining soil fertility including the use of organic manure, fertilizers and terracing. However poorutilization of inorganic fertilizers in both amounts and types is evident (Nandwaet al.,2001).Kakamega County has various drainage features such as River Yala, and River Nzoia. The riversare permanent due to heavy rains that occur in the area. Geomorphologic features determine thevegetation of the catchment area. There is an evergreen forest; Kakamega Forest, a preserve whichis a remnant of a rainforest that initially stretched west through Uganda. Agriculture is the main economic activity with $62 \%$ of the population involved mainly in cropfarming of maize and beans for subsistence use, tea, in some parts of the county, on small scale, and sugarcane as a major agricultural activity, largely on large scale in areas around Mumias.Animal keeping of local breeds and dairy farming is also practised on small scale (Ralph et al., 2005). The study area has a population of about $1,660,551$ people according to the 2009 population andhousing census with ratios of $48 \%$ men and $52 \%$ women but the population has been increasingrapidly over the years. The population density is 515 per square kilometer and has the following agedistribution (0-14 years at 46.6\%) 15-64 years (49.7\% while $65+$ years is at $3.6 \%$. There area approximately 358,709 households (CBS 2009). Most of the population tends to settle around townsand trading centres and Kakamega municipality has about 1485 persons per square kilometer.Annual population growth is estimated at $2.12 \%$. Rapid population growth has implications on landresources such as the depletion of water resources, cultivation of marginal lands, over cultivation leading to land degradation . This unsuitable land management practices have impacts on the long-term climatic trends of this area.

\subsection{Sampling procedure}

Kakamega County consists of 12 sub counties which have various agro- ecological zones with variations in soils, rainfall amounts and even the type of crops grown. All the agro-ecological zones constituted the study sites targeted for sampling the study households. The study made use of the Morgan table and out of a population of 353,700 households a sample size of 375 households was derived. This was later randomly sampled in each of the twelve sub-counties.In the next stage, stratified sampling was used to apportion the 375 households to the various agro-ecological zones and according to the number of households and thereafter a simple random sampling was used to choose the households and accordingly, sample size tabulation was obtained as shown in table1 below:

Table 1: Sample size Tabulations fromKrejcie and Morgan (1970)

\begin{tabular}{|l|l|l|}
\hline Sub county & $\begin{array}{l}\text { No. of } \\
\text { house } \\
\text { holds }\end{array}$ & $\begin{array}{l}\text { No. of Households } \\
\text { randomly picked }\end{array}$ \\
\hline Kakamega South & 23,144 & 24 \\
\hline Kakamega East & 34,177 & 36 \\
\hline Butere & 23,220 & 24 \\
\hline Kakamega Central & 40,121 & 43 \\
\hline Likuyani & 30,476 & 32 \\
\hline Malava & 21,635 & 24 \\
\hline Khwisero & 30,121 & 32 \\
\hline Mumias & 42,685 & 44 \\
\hline Navakholo & 25,020 & 25 \\
\hline Matungu & 36,485 & 38 \\
\hline Matete & 20635 & 22 \\
\hline Lugari & 29,121 & 31 \\
\hline Total & 353,70 & 375 \\
\hline
\end{tabular}

Source: KWBS (2009) Statistics

Adopted from Krejcie and Morgan (1970)

\subsection{Methods of Data collection and Analysis}

Both primary and secondary data was collected. Primary data included climate change adaptation strategies, crops grown, family sizes, education levels, gender; land tenure, farming experiences and farmers perceptions on climate change issues. This was collected using questionnaires administered to household heads who constituted the respondents. Interview schedules from key informants were used to gain information from agricultural officers and meteorological officers in various capacities in the county. Focal group discussions were used to collect extra data and validate the data that was collected from the other sources. 
The collected data was subjected to both quantitative and qualitative analyses using standard statistical packages to extract various information including household characteristics, climate change strategies and climate change trends of the area, status of livelihoods in the study area, constraints to livelihood improvements, and opportunities for poverty reduction as an incentive to crop production.

\subsubsection{Analysis of Climate Change Adaptation Strategies}

This research established the climate change strategies that are being used by farmers in the study area. The strategies were ranked accordingly to establish the most commonly used strategies for adaptation to climate change. The analysis was done thematically using the various themes that emerged from the data collected from the data collected and have several sub topics to evaluate on the various adaptation strategies. The findings were subjected to Spearman's rank correlation to establish if there were any correlations between certain variables and adaptation strategies.

\section{RESULTS AND DISCUSSIONS}

\subsection{Annual Rainfall trends in Kakamega County}

There is a general decline in the rainfall annual amounts for the period of study. Results in the figure 2 below indicate that there was a regression coefficient of -3.00 clearly indicating a negative linear trend in annual rainfall amounts as from 1968 to 2014. This implies that as the years went by, the annual rainfall amounts reduced and for every additional year, the rainfall amounts reduced by $3.00 \mathrm{~mm}$. The coefficient of determination $\left(\mathrm{R}^{2}\right)$ of the annual rainfall amounts is 0.020 which implies $2 \%$ of variation in rainfall amounts over period in time (1968-2014). This prediction shows that there is likely to be a reduction in the rainfall amounts the future years. As noted from the above graph, it is obvious that rainfall amounts in the study area have been declining over time. Since most crop farming in the area is dependent on the rains then this implies that crop production is likely to decline if no appropriate measures are put in place to address this problem. The scenario in itself implies that the climate is changing in the area and therefore need to have appropriate coping mechanisms towards this issue.

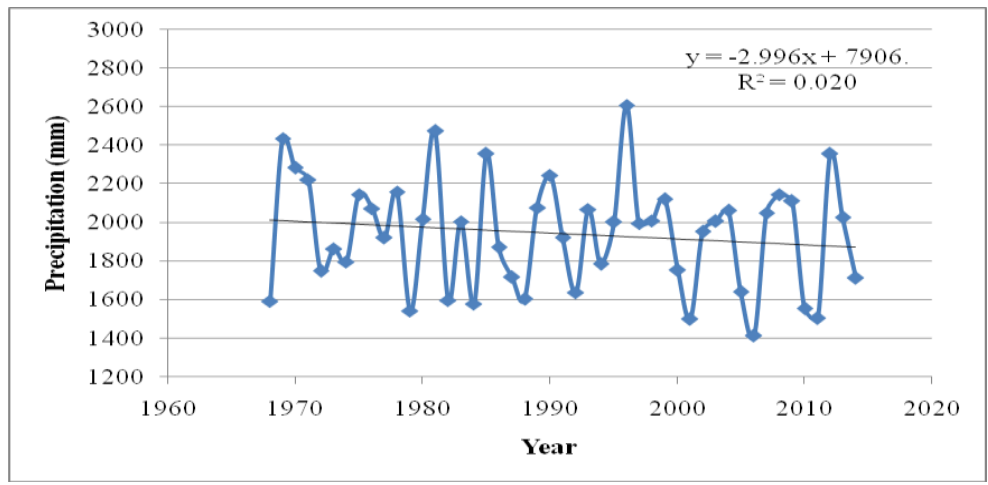

Figure 2: Annual Trend of rainfall amounts as from 1968 - 2014

\subsubsection{Farmer's perceptions to rainfall amounts}

This study sought to establish reasons for the changes in the onset of rainfall and the findings indicated that $25.9 \%$ of the respondents indicated that the change in onset of rainfall was inconsistent over the years, while another $25.9 \%$ of them indicated that the change in the onset of rainfall was due to seasonal variation. At the same time, $40.7 \%$ of the respondents indicated that the change was due to delays while another $7.4 \%$ of them indicated that there was early rain season.

\subsubsection{Annual Temperature trends in Kakamega County}

There is a positive linear trend in annual mean temperature as from 1994 to 2014 as indicated in the results in the figure 5.26 below indicate that there was a regression coefficient of 0.04 . The coefficient of determination $\left(\mathrm{R}^{2}\right)$ of the annual temperature is 0.433 which implies $43.3 \%$ of variation in temperature amounts over period in time (1994-2014). This implies that as the years went by, the annual mean temperature increased and for every additional year, the annual mean temperature increased by $0.04^{\circ} \mathrm{C}$. This prediction shows that there is likely to be an increase in annual mean temperature in the future years in the area. 


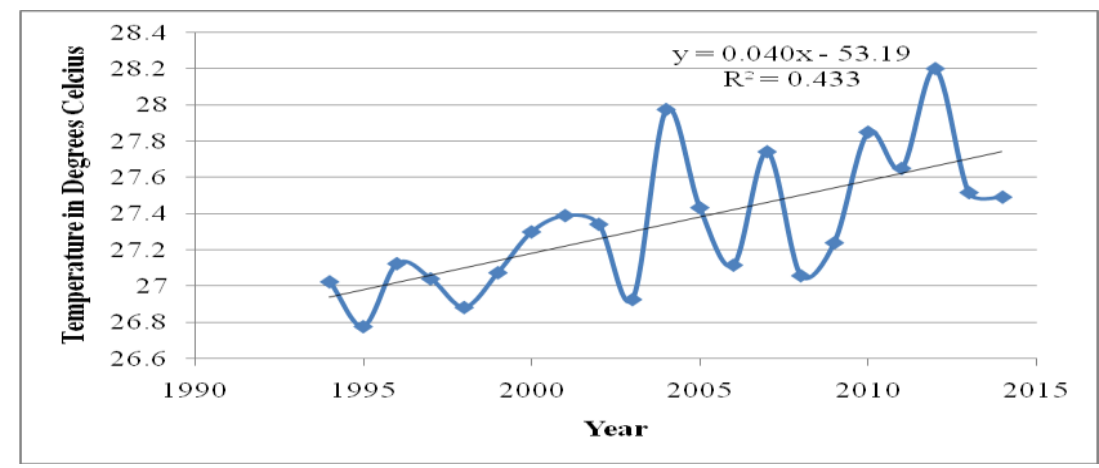

Figure 3: Annual trend of Mean Temperature as from 1994 to 2014

\subsubsection{Perceptions of farmers to temperature over the last 20 years}

This study found it necessary to establish the farmer's perceptions towards temperature as an indicator to climate change. All of the farmers were asked a dichotomous ("yes/no" response) question about whether or not they had experienced changes to regional climate within the past 20 years. After their initial response, they were asked about their perceived experience in relation to changes in temperature. To these they could respond that they had experienced decreases, increases, or no change in perceived changes in temperature. It was noted that $76.8 \%$ of the respondents reported that the number of hot days had increased while another $13.0 \%$ of them indicated that the number of hot days had declined. On the other hand, $10.1 \%$ of the respondents indicated that the number of hot days remained the same. There was need for this study to establish the causes as to the farmer's perceptions for long term changes in mean temperature over the last 20 years. $14.3 \%$ of the respondents reported that mean temperature changed due to deforestation and un sustainable land management practices. $33.9 \%$ of them indicated that the change in temperature was due to increase in certain months over the period of study. At the same time, $5.4 \%$ of the respondents revealed that change in temperarture was due to global warming while another $7.1 \%$ of them felt that the change in temperature was due to decrease in certaing months. Furthermore, $28.6 \%$ of the respondents felt that the change in temperature was due to inconsistency with another $10.7 \%$ of them indicating that the change in temperature was due to other including urbanisation,an increase in industries in the region.

\subsection{Adaptation strategies to climate change by farmers}

There was need to establish the adjustments made by the farmers on how they were coping with the increase in number of hot days and the findings are shown in Table 3below :

Table 2: Adaptation strategies made by farmers

\begin{tabular}{|l|l|}
\hline $\begin{array}{l}\text { Adjustments made according to } \\
\text { preference }\end{array}$ & Percentage \\
\hline Planting of drought tolerant crops & $17.1 \%$ \\
\hline Agroforestry & $15.0 \%$ \\
\hline Crop rotation & $14.3 \%$ \\
\hline Irrigation & $12.1 \%$ \\
\hline Planting early maturing crops & $10.0 \%$ \\
\hline Integrated farming practices & $10.0 \%$ \\
\hline Timely planting & $2.9 \%$ \\
\hline Integrated farming practices & $9.3 \%$ \\
\hline Rain water harvesting and storage & $2.9 \%$ \\
\hline Total & $100.0 \%$ \\
\hline
\end{tabular}

It is worth noting that farmers in the study area have endeavored to put into practice most of these adaptation strategies. Infact in most instances some farmers practiced more than one of the adaptation strategies concurrently. For example, there are cases where you find a farmer practicing three at the same time such planting of drought tolerant crops, agroforestry and crop rotation.Similar studies done elsewhere have revealed similar findings to this study noting that adaptation strategies take on socio- economic levels and characteristics of farmers for example more literate farmers may take different adaptive measures than illiterate ones. More over family income, farm sizes, farming experiences and contact with extension services influence the farmer's 
use of adaptive measures. (Mohammed et al.,2014 ). It is in this regard that this study endeavored to correlate the various variables which included age of respondents, gender, education levels, farming experiences, major crops cultivated with the adaptation strategies. This was mainly for purposes of finding out if the variables could be influencing on the way the farmers were adapting to climate change and if so do they have significant implications? Studies done in Bangladesh by Mohammed etal.,(2014),Uganda, Tanzania and even Senegal( IFPRI 2015) have findings that are in consonance that the various variables such as education levels, farming experiences, gender and even Age of the farmers will have an influence on the way farmers adapt to the changing climate. Studies done in Burkina Faso by West et.al., in 2008 were in consonance with the others indicating that rural households varied agricultural practices for example by integrating different crop varieties in their agricultural activities and implementing of soil and water conservation practices in order to respond to drought.

\subsection{Factors influencing coping strategies \\ 3.3.1 Age of farmers}

The study sought to establish the age of the farmers and if there is any correlation with adaptation strategies. The findings reveal that $17.1 \%$ of the respondents were between $20-24$ years while $10.5 \%$ of them were aged between 25 - 29 years. A further $18.4 \%$ of the respondents were aged between $30-34$ years while 9.2\% of them were aged between 35-39 years. At the same time, 7.9\% of the respondents were aged between $40-44$ years while $13.2 \%$ of them were aged between $45-49$ years. The respondents aged between $50-54$ years were $13.2 \%$ while another $6.6 \%$ of them were aged between $55-59$ years. Finally, the oldest respondents of over 60 years were 3.9\%.Most farmers within this region are those within the ages of 30-34 years and therefore these are people who are likely to understand well the issues involved in farming and therefore are armed with necessary information regarding climate change adaptation strategies that can be well achieved and adhered to. From this study the age variable has negative correlation with adaptation strategies to climate change. This implies that the probability of adaptation significantly decreases as the age of farmer increases. This can be assumed that the farmers could be having less interest or less incentive in taking climate change issues. Moreover the older farmers could be resistant to change and thus do not see the need of employing new technologies and would prefer the traditional modes of farming that they are familiar with other than adopting to new methods. Similar outcomes have been found and explained by Fusselet al., (2006).

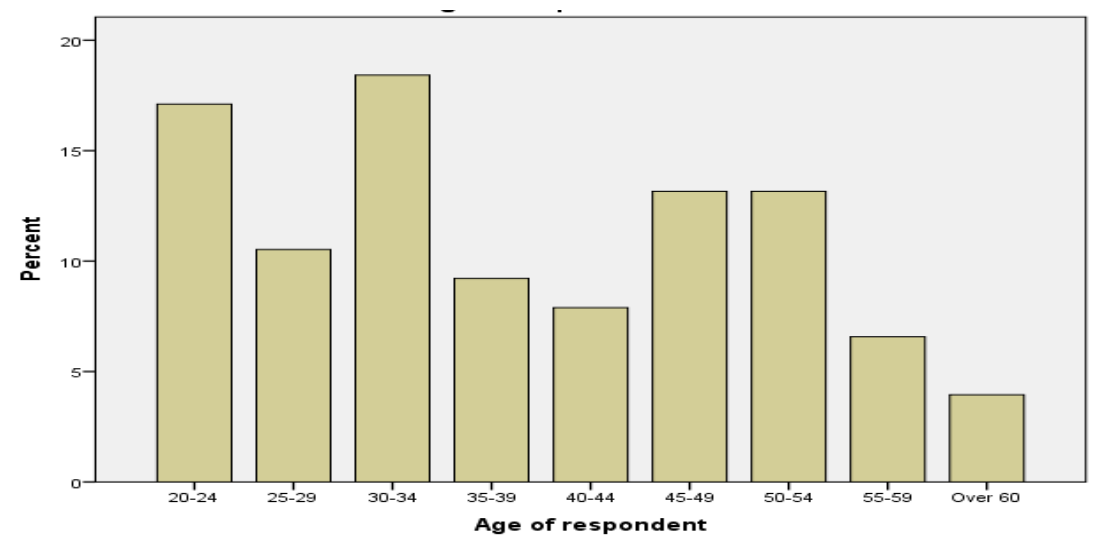

Figure 4: Respondents' Age

\subsubsection{Gender of farmers}

This study established the respondents' gender and notably majority of the respondents were male constituting $67.5 \%$ while females were $32.5 \%$. It is necessary to establish the differences in roles played by males and females in farm households since this gender differences are likely to influence their capacity to adapt to climate change as well as their choices of climate change adaptation strategies ( IFPRI, 2015).In many households in the study area most agricultural activities are planned by men and this meant that most women apart from those single headed households were left out on issues of agricultural production, climate change and even adaptation strategies that could be suitable in the area. It worth noting that $80 \%$ of women in Kenya are involved in agricultural activities such as weeding and harvesting but when it comes to agricultural planning/calendar they are left out. In most of African countries most decision regarding agricultural activities and planning have been left as preserve for the men who mainly focus on the end products from agriculture and not the processes. It is important to involve both the gender in the agricultural calendar.In Kenya and elsewhere, male and female have different roles and responsibilities on the farm. This means that the way of coping to climate change is also likely be different. Studies done in Kenya by IFPRI in 2015 from two different scenario one from western region( Nyando) and other in Eastern region( Wote) realized that the roles of males and 
females in agricultural activities showed considerable differences in decision making, roles, perceptions to climate change and shocks, access to information and even adaptation strategies. This study found out that $75 \%$ of women fromNyando could make decisions on how to use crops, sell, process and consume but only $30 \%$ could decide on how to spend the the income from the crops whereas their counterparts from Wote $80 \%$ of the females could make decisions on use of crops and $75 \%$ on how to use the income from the crops. In conclusion it simply means that men mainly make decisions regarding income from agricultural activities and yet it is the women who undertake the actual farm work.

\subsubsection{Levels of education}

It was necessary to establish the level of education of the farmers. This was done and the findings indicated that $10.0 \%$ of the respondents were of Primary level while a further $36.3 \%$ of them were at secondary school level. At the same time $26.3 \%$ of the respondents had reached tertiary levelwhile $27.5 \%$ of them had reached university level. There was need to establish if there was any significances in level of education of farmers and adaptions, notably from the findings there seemed to be no significant differences, even after findings of most of farmers having attained secondary level of education. This was measured using cross tabulation between levels of education and adaptation strategies adopted by farmers. The same information is shown in Figure --. Findings from this study indicate that there is positive correlation on levels of education and coping strategies to climate change. This indicates that the probability of farmers adapting to climate change seemed to be greater for those who have attained educational attainment as compared to the less educated farmers. It is obvious that educated farmers have more knowledge, greater ability to understand and respond to anticipated changes, can forecast future scenarios, have access to climate information and opportunities than the others which could encourage adaptation to climate change. Several studies elsewhere have found out that education levels of farmers also positively and significantly affect climate change adaptation such as those done in Bangladesh by Mohammed et. al., 2014).

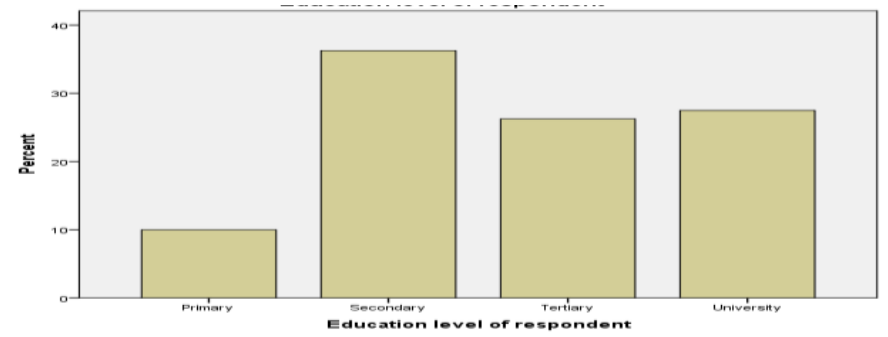

Figure 5 Respondents' Level of Education

\subsubsection{Family sizes of the farmers}

Family sizes play a vital role in adaptation strategies to climate change. This study therefore sought to establish household sizes for the families of the farmers who were our main respondents. The findings indicate that $46.8 \%$ of the respondents had a household size of below 4 individuals while $43.0 \%$ of them had a household size of between $5-9$ individuals. At the same time, $6.3 \%$ of the respondents had household sizes of between 10 - 14 individuals while $3.8 \%$ of them had households of above 15 people. The findings are also shown in Figure 4.3. Household sizes are necessary for one to understand how the members are involved in various aspects of farming. Secondly it was necessary so that we could deduce implications of family sizes such as, maybe larger families could be straining on family resources and even income from farming hence hindering climate change adaptation. Unfortunately, family sizes had a negative relationship with the adaptation to climate change. This implies that with an increase in family size the probability of adaptation was decreasing. This is in line with similar studies undertaken by Deressaet.al.,2008; Mignounaet al,. 2011.

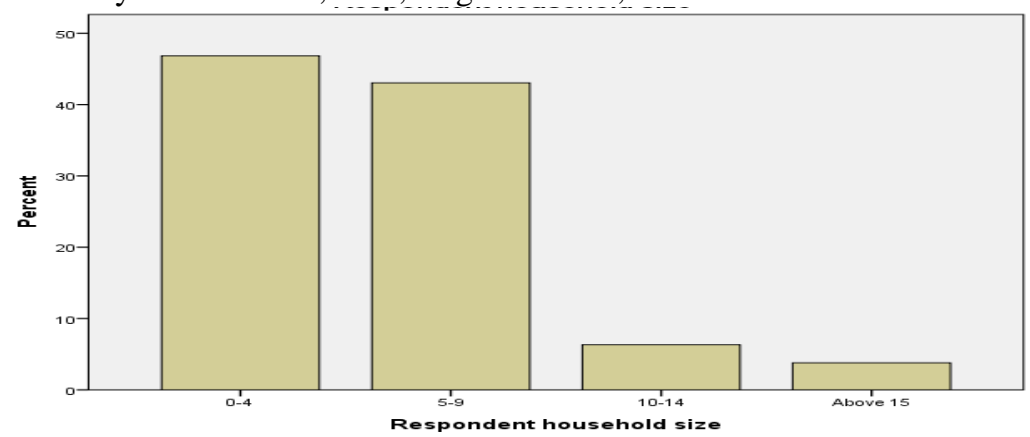

Figure 6: Respondents' Household sizes 


\subsubsection{Farming experiences of the respondents}

Farming experience is an important aspect in agriculture. Notwithstanding the number of years one has been involved in agricultural activities, one can be able to even predict their production, understand certain scenarios involved in farming and gain more information and knowledge with regard to whatever farming they are involved in.The study further established the respondents' farming experience and it was revealed that $16.5 \%$ of the respondents had a farming experience of between $0-4$ years while $30.4 \%$ of them were had a farming experience of between $5-9$ years. A further $8.9 \%$ of the respondents had farmed for between $10-14$ years while $10.1 \%$ of them had farmed for between $15-19$ years. At the same time, $15.2 \%$ of the respondents had been involved in farming for a period of between $20-24$ years while $16.5 \%$ of them had farmed for a period of between $25-29$ years. Finally, $2.5 \%$ of the respondents had been farmers for a period of over 30 years.

\subsubsection{Monthly Incomes from farming activities}

This study found it necessary to establish the farmers monthly income. Results indicate that $1.3 \%$ of the respondents had a monthly income of below Ksh. 5000 while $20.5 \%$ of them had a monthly income of between Ksh. 5,000 -10,000. A further $48.7 \%$ of the respondents had a monthly income of between Ksh. 10,000 - 20,000 while $29.5 \%$ of them had a monthly income of over Ksh. 20,000. This study revealed a positive association between family income and adaptation to climate change. It implies that farmers with high income levels are likely to adapt to climate change than farmers with lower income. These findings are in consonance with other studies which indicate that farmers that engage in off farm activities can diversify their income and continue with their agricultural operations in face of climatic uncertain activities. Kim et al., 2009 found out that household income positively and significantly influenced the adoption of adaptive climate change while Gbetibou , 2009 , explained that farmers with higher incomes are likely to embrace and will be interested in adapting by changing practice and modern methods such as irrigation to cope with the changing climate.

\subsubsection{Farm sizes of farmers}

The study further established the respondents average farm sizes. See Table 3 below for the findings.

Table 3: Average Acreage of farm sizes

\begin{tabular}{|l|l|}
\hline Farm Size & Percentage (\%) \\
\hline $0-1$ ha & 35.4 \\
\hline $2-3$ ha & 40.5 \\
\hline $4-5$ ha & 15.2 \\
\hline $6-7$ ha & 3.8 \\
\hline $8-9$ ha & 1.3 \\
\hline Above 10 ha & 3.8 \\
\hline Total & 100.0 \\
\hline
\end{tabular}

The data in the table reveal that $35.4 \%$ of the respondents had an average farm size of between $0-1$ hectares while $40.5 \%$ of them had a farm size of between $2-3$ hectares. A further $15.2 \%$ of the respondents had average farm size of between $4-5$ hectares while 3.8\% of them had farm size for between $6-7$ hectares, additionally $1.3 \%$ of the respondents had involved in farm size of between $8-9$ hectares while $3.8 \%$ of them had farm size of between above 10 hectares. This was necessary to establish if farm sizes had an influence on the way farmers adapted to climate change as it well known that if farming is taken as business the chances of farmers being keen on production and yields will be given a priority as compared to those that take farming merely as a tradition. The findings indicated a negative correlation between farm sizes and adaptation strategies. This implies that with an increase in farm sizes the probability of farmers adapting to climate change declined. This could be attributed to large farms employing traditional methods and technologies other than modern technologies to climate change adaptation. Moreover larger farms require a lot of investment to implement these adaptive strategies to climate change. Secondly this could be attributed to lack of proper management and supervision in relation and hence large farms tend to fail to adapt efficiently. Studies done by Mohammed et al., 2014 in Bangladesh had similar findings regarding adaptation strategies and farm sizes.

\section{CONCLUSION AND RECOMMENDATION}

From the study, it is noted that Kakamega County is generally experiencing changes in its rainfall amounts. The rainfall amounts are declining. This implies that as the years went by, the annual precipitation reduced and for every additional year, the precipitation reduced by $3.00 \mathrm{~mm}$. This prediction shows that there is likely to be a reduction in the precipitation in the future years. In addition, it was established that, just like most parts of the world are experiencing increase in temperature, Kakamega County is no exception. It has an upward 
trend of about $0.04{ }^{0} \mathrm{c}$ yearly.In order to overcome the effects of the aforesaid climatic changes, most small scale farmers in the county have embraced various coping mechanisms. Most common strategies employed include: Involvement in off farm activities, changing form purely crop farming to keeping of livestock and poultry, Taking insurance covers to cushion them from the severe crop losses, soil conservation practices such as mulching; use of animal manure/compost, crop diversification and even growing of drought tolerant and fast maturing crops, accessing credit facilities, and leasing of land among others. There are various factors that have influenced the coping strategies to climate change in climate change in Kakamega and they include education levels, gender, age and farming experiences of the farmers and to add up family sizes, farm sizes, family incomes played a major role in the coping of the farmers.Despite all the effort and measures put in place by these small scale farmers there are several barriers that are slowing them from appropriately adapting to the changing climate. These include mainly lack of finances, lack of climate information, lack ofexpertise in implementation of some of the methods, lack of extension services, and even culture.

\section{REFERENCES}

[1] Bryan, E., T.T. Deressa, G.A.Gbetibouo, and C.Ringler.( 2009). Adaptation to ClimateChange in Ethiopia and South Africa: Options and Constraints. Environmental Science and Policy12:413-426.

[2] Central Bureau of Statistics, (1999) Ministry of planning and National Development.

[3] Deressa, T.T. (2008). Measuring the Economic Impact of Climate Change on Ethiopian Agriculture: Ricardian Approach.CEEPA DP25, South Africa: University of Pretoria.

[4] Deressa, T., Hassan, R., Ringler, C., Alemu, T., \&Yesuf,M. (2008). Analysis of the determinants of farmers' choice of adaptation methods and perceptions of climate change in the Nile basin of Ethiopia.IFPRI Discussion Paper No. 798, Washington. Retrieved from http://www.ifpri.org/sites/default/files/publications/rb15_09.pdf

[5] FAO, (1986b) Tropical Forestry Action Plan Committee on Forest Development in Tropics, UN food and Agriculture Organization, Rome February 12, 2010.

[6] Food and Agriculture Organization of the United Nations (FAO) Kenya. (2007). Food security district profiles: District profiles for 23 districts. Available at www.fivims.org/, last accessed November, 2011.

[7] Food and Agriculture Organization of the United Nations (FAO) Kenya. (2007). Food security district profiles: District profiles for 23 districts.available at www.fivims.org/, last accessed November, 2011.

[8] Gbetibouo, G.A, (2009). Understanding Farmers' Perceptions and Adaptations to Climate Change and Variability: The Case of the Limpopo Basin, South Africa. IFPRI Discussion Paper 00849.Available:http://www.ifpri.org/sites/default/files /publications/rb15_08.pdf

[9] GOK (1994).The Kenya National Environment Action Plan (NEAP) Report.GOK (2013).National Climate Change Action Plan.Nairobi, Republic of Kenya.

[10] Intergovernmental panel on climate change (2007). Mitigation, Contribution of working group 111 t0 Fourth assessment Report on Intergovernmental Panel on ClimateChange, Cambridge University Press, United Kingdom and New York NY U.S.A

[11] International Food Policy Research Institute, (2009). Washington, D.C. Climate ChangeImpact on Agriculture and Costs of Adaptation, Gerald C. Nelson, Mark W. Rosegrant, Jawoo Koo, Richard Robertson, Timothy Sulser,Tingju Zhu, Claudia Ringler, SiwaMsangi, Amanda Palazzo, Miroslav Batka, Marilia Magalhaes, Rowena Valmonte-Santos, Mandy Ewing, and David Lee.

[12] IPCC (2001).Climate Change 2001: Impacts, Adaptation, and Vulnerability, Contribution of Working Group II to the Third Assessment Report of the Intergovernmental Panel on Climate Change, Cambridge University Press, UK

[13] IPCC 2007. Summary for Policymakers. In: Climate Change( 2007): The Physical Science Basis. Contribution of IPCC, 2007: Climate Change 2007: Impacts, Adaptation, and Vulnerability. Contribution of Working Group II to the Third Assessment Report of the Intergovernmental Panel on Climate Change [Parry, Martin L., Canziani, Osvaldo F., Palutikof, Jean P., van der Linden, Paul J., and Hanson, Clair E. (eds.)]. Cambridge University Press, Cambridge, United Kingdom, 1000 pp.

[14] IPPC (1996).Climate change Impacts, adaptation and mitigation of climate change Scientific Technical Working Group II.Cambridge University Press.

[15] IPPC (2007).(Intergovernmental panel on Climate Change 2007C, Fourth Assessment Report, Climate Change AR4.

[16] Kothari, C.R.(2004).Research Methodology: Methods And Techniques. Second Revised Edition ed. New Age International.p. 418.

[17] Krejcie, R.V., \& Morgan, D.W, (1970). Determining Sample Size for Research Activities. Educational and Psychological Measurement 
[18] Macharia, P.N., Lugadiru J., Wakori S., Ng'ang'a L.W, and Thuranira E. (2010). Perceptions and adaptation measures to climate change and variability by immigrant communities in semi-arid regions of Nyeri North and Laikipia East districts.12th KARI Biennial Conference 8-10 November 2010, Nairobi, Kenya.Availableat www.kari.org/biennialconference/conference12/docs/PERCEPTIONS\%20AND\%20ADAPTA TION\%20MEASURES\%20TO\%20CLIMATE\%20CHANGE.pdfBrien K. And Leincheko R (2000).Double exposure: Assessing the impacts of climatechange within context and globalization" Global environmental change10 (221-2320

[19] Oxfam. (2005). Climate Change impacts on Development: A Note of Oxfam's Experience for the Stern Review. $\quad$ www.oxfam.org.uk/resources/policy/climate_change/downloads/climatechange_oxfam_stern.P.J. van der Linden and C.E. Hanson, Eds., Cambridge University Press, Cambridge, UK, 7-22. 28

[20] Ralph, J., Helmut, S., Berthold, H., and Chris S., (2005). Farm Management Handbook of Kenya, Natural Conditions and Farm ManagementInformation. 2nd Edition, Volume II, PART A WEST KENYA.

[21] Raswant et al., (2008).Biofuel Expansion: Challenges, Risks and Opportunities for Rural Poor People. Paper prepared for the Round Table organized during the Thirty-first session of IFAD's Governing Council. Rome.

[22] Regassa, S. Givey C and Gina E. (2010). The rain doesn't come on time anymore. Oxfam International Research Report.

[23] Vogel, C., and K. O’Brien.( 2006). Who can eat information? Examining the effectiveness of seasonal climate forecasts and regional climate-riskmanagement strategies. Climate Research33: 111-122.

[24] Watson et. al., (1998).Protecting our planet, securing our future - linkages among global environmental issues and human needs. Nairobi, Kenya and Washington, DC, USA, United Nations Environment Programme (UNEP), United States National Aeronautics and Space Administration (NASA) and World Bank.

[25] West, C., Roncoli C, .Ouattara F.( 2008). Local Perceptions and Regional Climate Trends on the Central Plateau of Burkina Faso.Land Degradation Development19:289-304.

[26] Woodhill J., Terwisscha Van Scheltinga T,(2007). Supporting Capacities for Climate Change Adaptation In Eastern Africa, Wageningen UR Strategy \& Policy Brief \#1, July 